\title{
ANALYSIS OF THE RETAIL TRADE AND AUTOMOTIVE INDUSTRY IN THE RUSSIAN FEDERATION
}

\section{Bolotov, I.}

The article examines recent developments in the Russian retail trade and automobile industry as two very dynamic sectors of the Russian economy by stating and forecasting sales trends, presenting the main market participants, shares of business forms and deducing perspectives for Central and Eastern European investors. The article uses a standard methodology for description of industries and econometric models for sales forecasts and analysis. The article's main benefit for Central and Eastern European managers is its concise and up-to-date description of the both sectors of the Russian economy, which is not easily accessible for foreigners due to language barriers and marketing agency fees.

JEL classification: L62, L81, M31, O52

Keywords: Russian market; retail trade; automotive industry; perspectives; forecasts.

\section{Introduction}

In view of the growing concentration of Central European markets, many companies (for example, in the Czech Republic) seek to diversify their activities, especially, towards Eastern Europe and Asia. The Russian Federation (RF) offers many possibilities to Central and Eastern European businesses due to its big size (a market of more than 140 million potential customers), cultural closeness to Central Europe (Slavonic origin of the majority of population, common socialist past etc.), knowledge of the Russian language among Central Europeans, positive image of Central and Eastern European goods and services among Russian customers and many other strengths. An important question for many investors, nevertheless, remains the choice of industry. This article aims to help resolve this problem by analyzing the development of two very dynamic Russian industries, retail trade and the automotive sector, by answering the following research question "What are the main specifics of Russian industries?" and by testing one hypothesis:

H1: Retail trade and automobile industry sales show a promising perspective in the decade 2010-2020.

\section{Methods}

The article is based on a standard model of industry description, used e.g. in (Machek 2012), consisting of stating and analyzing 1) sales development, 2) top market participants, their origin and concentration and 3) specifics and perspectives of the market. Econometric tools for time series analysis, used where possible, include one-dimensional time series $\operatorname{ARIMA}(p, q, r)$ model, and multi-dimensional co-integration regression model, based on (Engel and Granger, 1987) methodology. The principle source of data is the Russian statistical office (Rosstat) and studies of the 'Big Four' (KPMG, PwC, EY and Deloitte). Preliminary research on the topic was presented in Bolotov (2013).

\section{Industry Composition of the Russian Federation}

To justify the choice of the two industries, it is necessary to examine the industry composition of the Russian economy. From Appendix 1, it is perceivable that according to the OKVED classification, its main sectors were, in 2012, wholesale and retail trade (ca. $20 \%$ ), manufacturing industries (ca. $15 \%$ ), real estate activities (ca. 
$12 \%$ ) and mining and quarrying (ca. $11 \%$ ). Compared to the pre-1991 (socialist) period, when manufacturing dominated the economy and there was a lack in choice of consumer goods, it is not difficult to deduce that $\mathrm{B} 2 \mathrm{C}$ retail trade and automotive industry should be nowadays of importance in the RF. Moreover, due to a historical development different from that in Central Europe, both retail trade and the automotive industry in the RF show certain specifics.

\section{Retail trade in the Russian Federation}

Machek (2012), based on Dries, Reardon and Swinnen (2004), defines three stages in the retail trade development in Central and Eastern Europe: pre-transition (communist / socialist, before 1989/1991), transition ('small privatization', first half of the 1990s) and globalization period (second half of the 1990s and nowadays). The retail trade development in the RF does not, however, exactly fit this scheme.

\subsection{Dependence on the Economic Policy of the Government}

Retail trade turnover in the RF has been growing at a relatively stable pace for 40 years, with exception of the transition period (1986-1994). Socialist times were marked by relatively constant figures (similar to Central and Eastern European countries), transition by stagnation and fall, and the 2000 s by rapid growth of ca. $22 \%$ per year, which dropped to $4.7 \%$ in the crisis year of 2009 but recovered to $13 \%$ and $15.7 \%$ in 2010 and 2011, attaining ca. 19,082,577.6 million RUB (457,929.8 million EUR) in 2011. Forecasts (with the help of $\operatorname{ARIMA}(1,0,1)$ model), based on monthly data, 2000-2012, also point to continuous growth and an increase of more than $50 \%$ by 2020 (see Figure 1), which makes the industry lucrative for foreign, among other, Central and Eastern European, investors in the long run.

This growth is, however, not primarily caused by intensifying globalization (growing presence of multinational players, which is much lower in Russia, compared with Central and Eastern Europe), but by improvements in the living standard of the population. The degree of the so-called 'Wall-Mart effect' (Igan and Suzuki, 2012), declining prices due to concentration in the retail trade, is also lower, which can be econometrically proven for the Russian retail industry on monthly data, 2000-2012, with the help of the following (co-integration regression) model:

$$
C P I_{t}=b_{0}+b_{1} x T R_{t}+e_{t}
$$

Figure 1: Recent development and long-term forecasts of retail trade turnover in the RF, million RUB

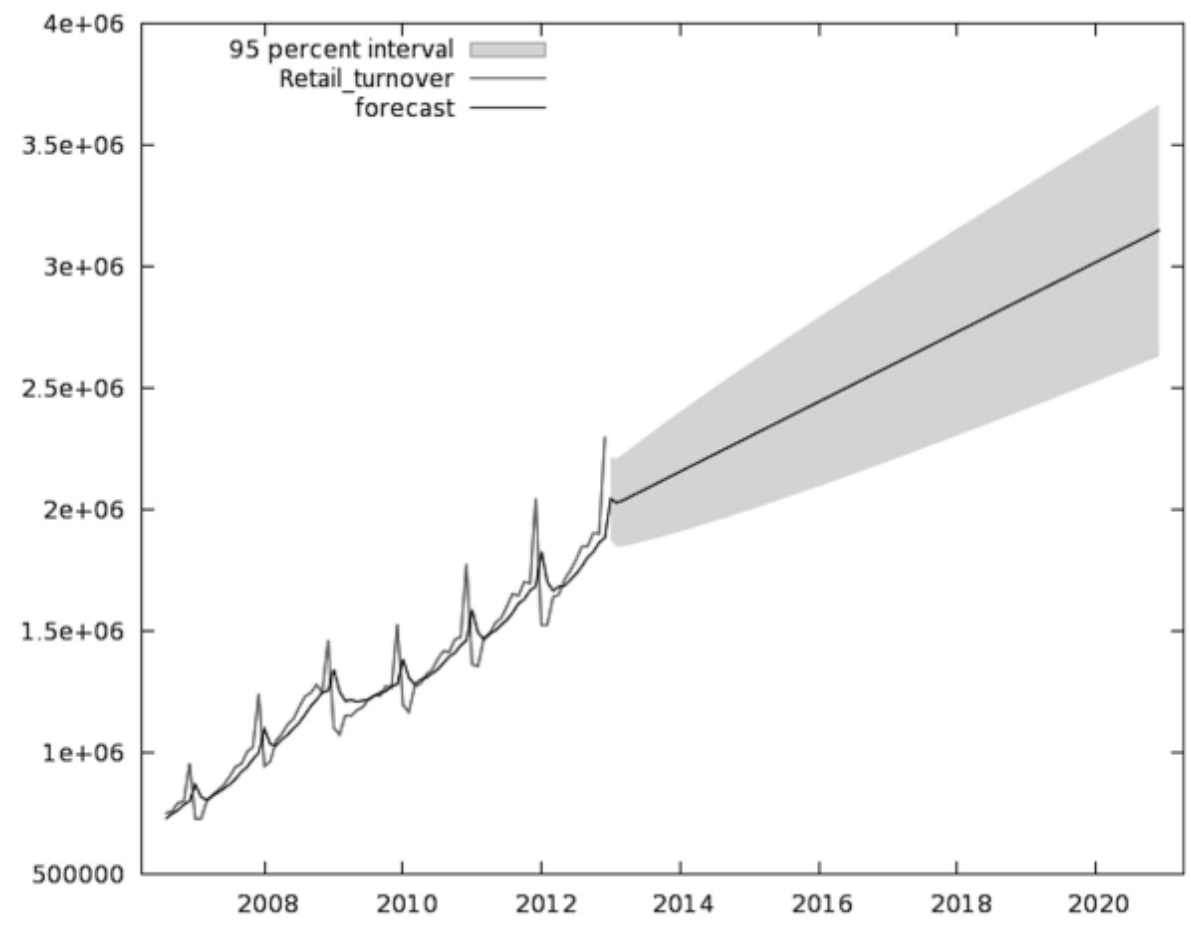

Source: Author, Rosstat data. 
Figure 2: Sales in the retail industry by main product groups and company types, million RUB

Source: Author, Rosstat data.

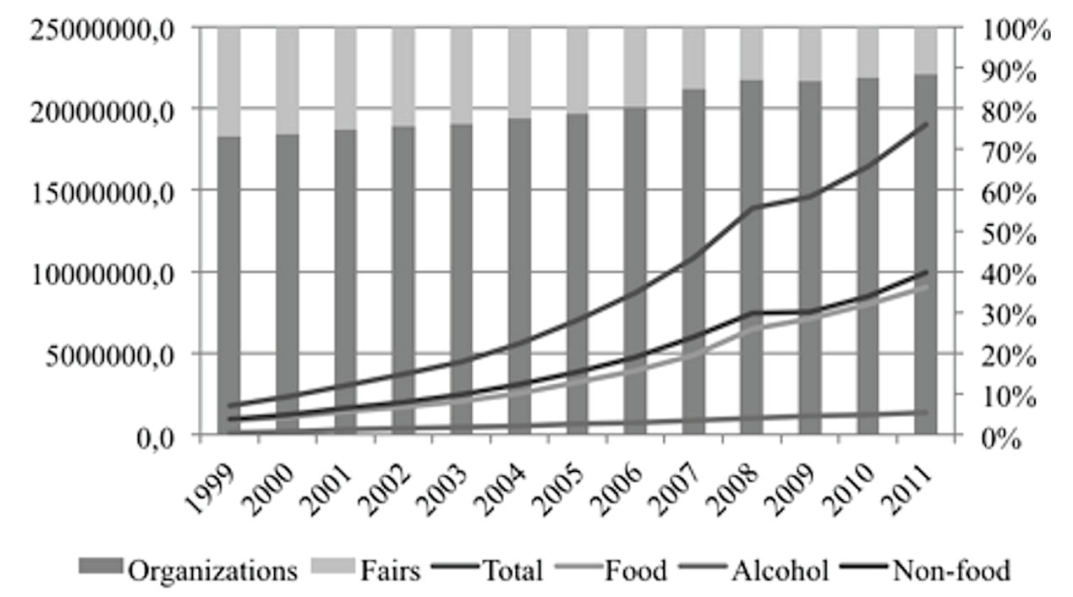

where $C P I_{t}$ and $T R_{t}$ are consumer price index and retail turnover, and $b_{0}, b_{1}$ and $e_{t}$ are the two parameters and errors. According to unit root (Augmented Dickey-Fuller, ADF) tests, there is a long-term relationship between $C P I_{t}$ and $T R_{t}$ at the $10 \%$ significance level (after correction for autocorrelation by the Cochrane-Orcutt method, $b_{0}=101.405(0.155708)$ and $\left.b_{1}=-5.74648 \mathrm{e}-07(1.51574 \mathrm{e}-07)\right)$ with a quality of the model $\left(R^{2}\right)$ of ca. $38.9945 \%$, which is below $50 \%$, and with an unclear causality (according to the so-called Granger causality test, there is a both-way dependence between turnover and price level). This questions the significance of the 'Wall-Mart effect' in the RF in the last 12 years.

Table 1: Top eight companies in the Russian retail industry in 2010

\begin{tabular}{|c|c|c|c|c|c|c|}
\hline No. & & Brands & Focus & $\begin{array}{l}\text { Turnover, } \\
\text { billion RUB } \\
\text { after VAT }\end{array}$ & $\begin{array}{l}\text { Number } \\
\text { of shops, } \\
\text { end } 2010\end{array}$ & $\begin{array}{c}\text { Present in FD } \\
\text { (Federal Districts) }\end{array}$ \\
\hline 1 & $\begin{array}{l}\text { X5 Retail Group } \\
\text { (No. } 2 \text { in 2013) }\end{array}$ & $\begin{array}{l}\text { Карусель, Пятерочка, } \\
\text { Перекресток, Копейка }\end{array}$ & Food & 396.22 & 2469 & $\begin{array}{l}\text { Central, North-western, } \\
\text { Southern, Urals, Volga FDs }\end{array}$ \\
\hline \multirow[t]{2}{*}{2} & Auchan Group & $\begin{array}{l}\text { Ашан, Ашан-Сити, } \\
\text { Радуга, Атак, Леруа }\end{array}$ & $\begin{array}{l}\text { Food, } \\
\text { household } \\
\text { goods }\end{array}$ & 256.16 & 111 & $\begin{array}{l}\text { Central, Southern, } \\
\text { Northwestern, Volga, } \\
\text { Siberian, Urals FDs }\end{array}$ \\
\hline & & Мерлен, Декатлон & $\begin{array}{l}\text { Repairs, } \\
\text { sport }\end{array}$ & & & \\
\hline 3 & $\begin{array}{l}\text { Magnit } \\
\text { (No. 1in 2013) }\end{array}$ & $\begin{array}{l}\text { Магнит, } \\
\text { Магнит-Косметик }\end{array}$ & $\begin{array}{l}\text { Food, } \\
\text { household } \\
\text { goods, } \\
\text { cosmetics }\end{array}$ & 236.19 & 4055 & $\begin{array}{l}\text { Southern, Central, Urals, } \\
\text { North-western, Volga, } \\
\text { North Caucasian, Siberian } \\
\text { FDs }\end{array}$ \\
\hline 4 & Metro Group & $\begin{array}{l}\text { Метро Кэш энд Кэрри, } \\
\text { Реал, Медиа Маркт, } \\
\text { Сатурн }\end{array}$ & $\begin{array}{l}\text { Food, } \\
\text { household } \\
\text { goods }\end{array}$ & 170.26 & 104 & $\begin{array}{l}\text { Northwestern, Central, } \\
\text { Siberian, Southern, Urals, } \\
\text { Volga FDs }\end{array}$ \\
\hline 5 & M.Video & М.Видео & $\begin{array}{l}\text { Household } \\
\text { goods }\end{array}$ & 86.39 & 230 & all FDs \\
\hline 6 & O’Kay & О`Кей, О`Кей-экспресс & Food & 82.67 & 57 & $\begin{array}{l}\text { Northwestern, Southern, } \\
\text { Central, Siberian, Volga, } \\
\text { North Caucasian FDs }\end{array}$ \\
\hline 7 & $\begin{array}{l}\text { Eldorado (is now } \\
100 \% \text { owned by the } \\
\text { Czech PPF group) }\end{array}$ & Эльдорадо & $\begin{array}{l}\text { Household } \\
\text { goods }\end{array}$ & 80.00 & 331 & all FDs \\
\hline 8 & Lenta & Лента & Food & 70.60 & 39 & $\begin{array}{l}\text { Siberian, North-western, } \\
\text { Southern, Volga, Urals FDs }\end{array}$ \\
\hline
\end{tabular}

Source: Kommersant.ru and InfoLine, the Retailer Magazine, 2010. 


\subsection{Market Structure - Forms}

The rapid growth of retail trade turnover in the RF in 2000s concerns equally food and non-food products and is marked by a decrease in the share of traditional street vendors and fairs; see Figure 2. GfK (2007, the last major study on Russian retail forms) published the following statistics on forms of retail trade in the RF: hypermarkets (3.4\%), supermarkets (9.3\%), discounts (9.3\%), Cash \& Carry $(0.8 \%)$, small grocery shops $(32.9 \%)$, traditional street markets and fairs $(18.4 \%)$, others (26\%). To compare, the first three mentioned forms constituted ca. $60 \%$ in Central European countries (GfK, 2012). Hypermarkets and supermarkets, nevertheless, remained the most dynamic forms of retail business in the Russian market in 2012-2013, according to surveys (Ernst and Young, 2011).

\subsection{Market Structure - Biggest Companies}

A list of the eight (data for TOP10 was not available at the time of elaboration of this article) biggest companies in the Russian retail industry in 2010 is presented in Table 1.

It is perceivable that most companies are multi-form and of Russian origin, of which the most dynamic players are Magnit and the X5 Retail Group (No. 1 and 2 in 2013, Magnit was also listed among the top 10 Russian companies with the biggest market capitalization in 2013).
The only foreign companies are German Metro, French Auchan and Czech PPF Group, with a share of 36.5\% in the Top 8 (which is a very low figure for Central and Eastern Europe). The share of Top 8 in total retail trade turnover was ca. $7.27 \%$ in 2010. To compare, the Top 10 in the Czech Republic constituted $76.5 \%$, in Hungary $65.4 \%$ and in Poland 57.9\% (Drtina, 2010). The Russian retail market, therefore, remains less saturated and open for foreign companies (however, as often indicated in the daily press, concentration is slowly strengthening over time).

\section{Automotive Industry in the Russian Federation}

Official Russian statistics distinguish between four types of vehicles: passenger vehicles (B2C / car), light commercial vehicles, trucks and buses. In this article, the attention is focused on the biggest of the segments, the B2C market, and its development, see Figure. 3.

\subsection{Volatility, Perspectives and Main Problems}

The Russian Ministry of Industry and Trade's (Minpromtorg's) "Strategy for the automobile industry for 2009-2020" (Minpromtorg, 2009), divides the development of the Russian automotive sector into four phases: the growth and stagnation of the $1990 \mathrm{~s}$, the lag overcoming and the crisis of the first decade of the 2000s (peaking at 2.8 million sales a year) and the recovery and

Figure 3: The development of the Russian car market and Minpromtorg previsions, million units

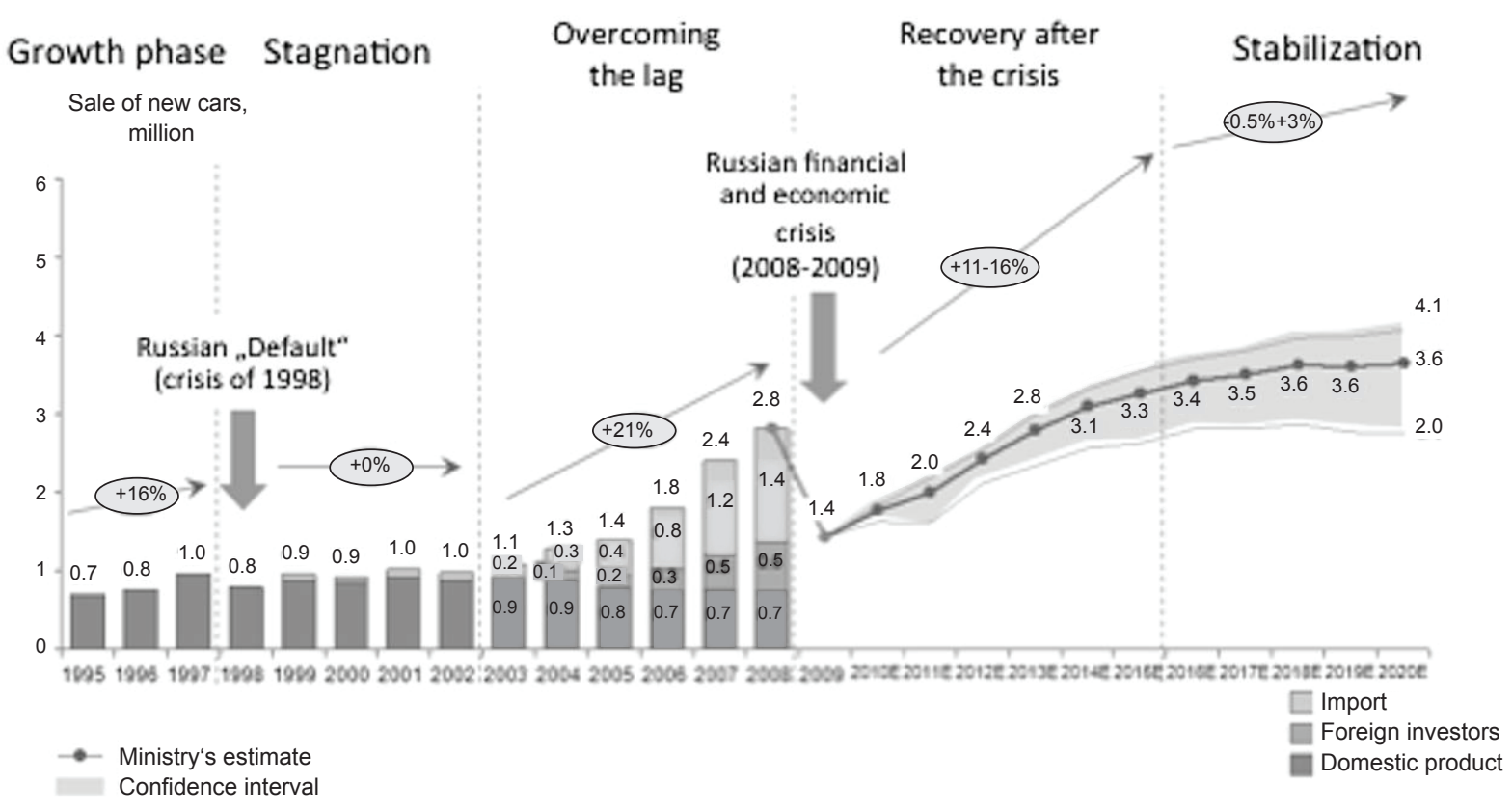

Source: Minpromtorg (2009, p. 18). 
Figure 4: International comparisons in the automotive industry in 2008

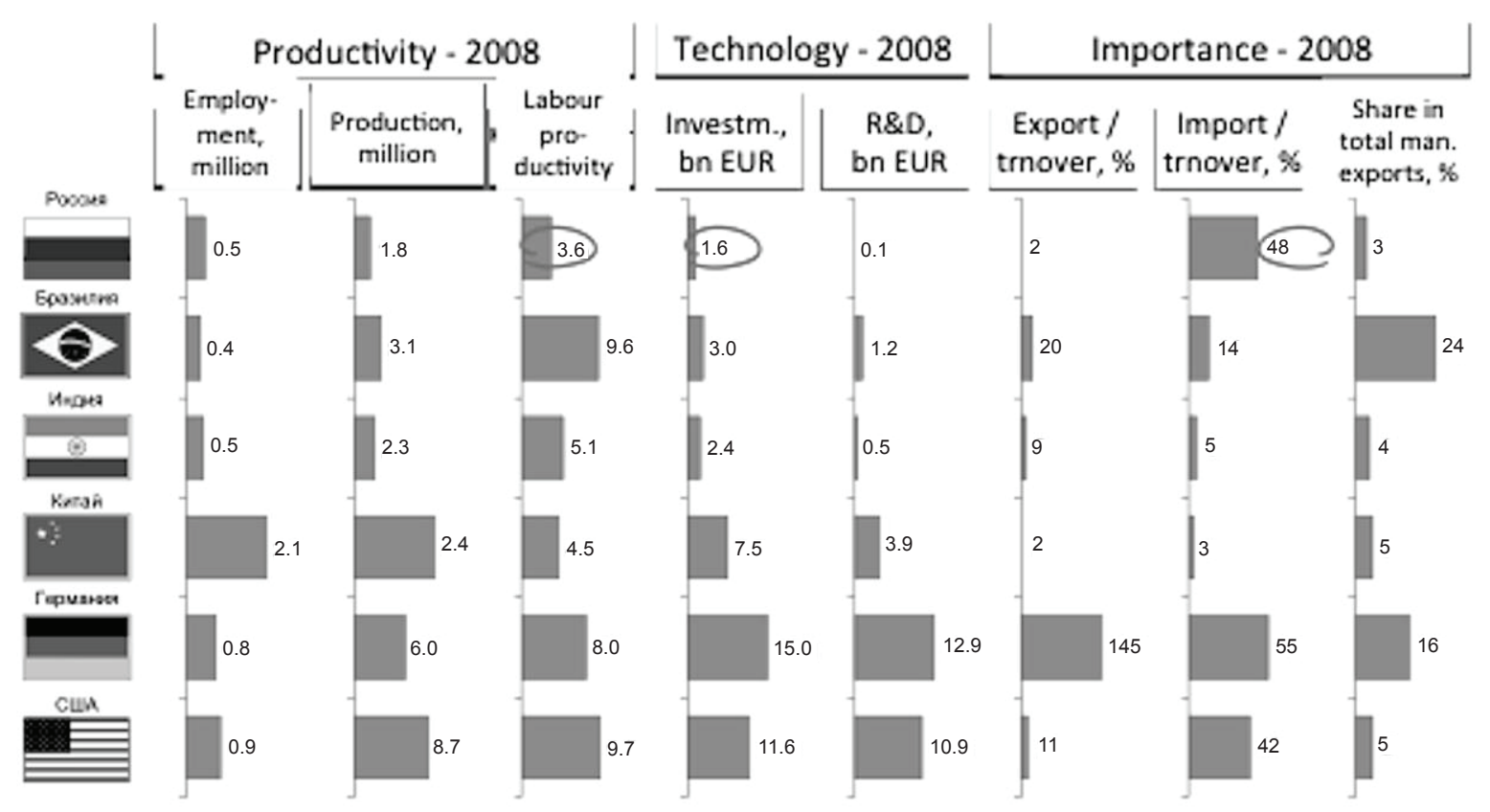

Note: Countries from top to bottom - Russia, Brazil, India, China, Germany, the USA. Source: Minpromtorg (2009, p. 34).

stabilization of 2010-2020. According to the Ministry's forecasts (which is the only long-term prediction in the field, as corresponding data are not publicly available), the average growth of $21 \%$ in 2000-2010 should be replaced by the $11-16 \%$ increase in $2010-2015$ and $-0.5-3 \%$ growth / stagnation in 2015-2020 (with the maximum of 3.6 million new car sales per year, a ca. $25 \%$ increase over the values of 2008).

Ernst and Young's research (Ernst and Young, 2013), however, states that post-crisis recovery in the Russian automotive industry was mainly created by government support and may slow down in coming years. Government support has been reduced following the accession of Russia to the WTO in 2012 (Russia will, however, have a six-year transitional period for the automotive industry). These factors will mostly affect less competitive domestic (traditional) producers whose share in new car sales is decreasing in time and fell down at the level of $25 \%$ in 2008 . On the contrary, the share of imports and foreign-investment-based production is rapidly growing (1.4 and 0.6 million new sales in 2008). The Russian car market therefore offers very promising perspectives for foreign companies, especially for Central and Eastern European traditional automotive manufacturers.

The automotive industry, however, belongs among the least competitive ones in the Russian economy and inter- nationally (except import turnover), and has recently been surpassed by China, a non-traditional automobile producer, in all important indicators; see Figure 4.

\subsection{Market Structure - Forms}

According to Minpromtorg (2009), the automobile industry in Russia counts ca. 400 companies with 400,000 workers, extending to 4.5 million employees after including all of the industry's suppliers, and with ca. $1 \%$ share in the Russian GDP (a much lower share compared with the retail and wholesale trade). Russian statistics distinguish between four types of companies present in the automotive industry: 1) domestic automobile manufacturing firms, 2) firms controlled by foreign investors (so-called 'localized producers'), 3) producers of components and 4) importers of foreign production (e.g. in Saint Petersburg and in Vladivostok).

The least typical type of company is the component producers, as, according to (Minpromtorg 2009), TNCs specialized in this domain are not yet eager to enter the Russian market on a large scale. The spatial distribution of TNCs is shown in Figure 5.

Table 2 and Figure 6 present the biggest Russian automobile producers and the top brands in the Russian car market. It can be seen that in 2011, $49 \%$ of the market was divided among foreign brands (with the Russian 
Figure 5: Foreign producers of automotive components in Russia, map

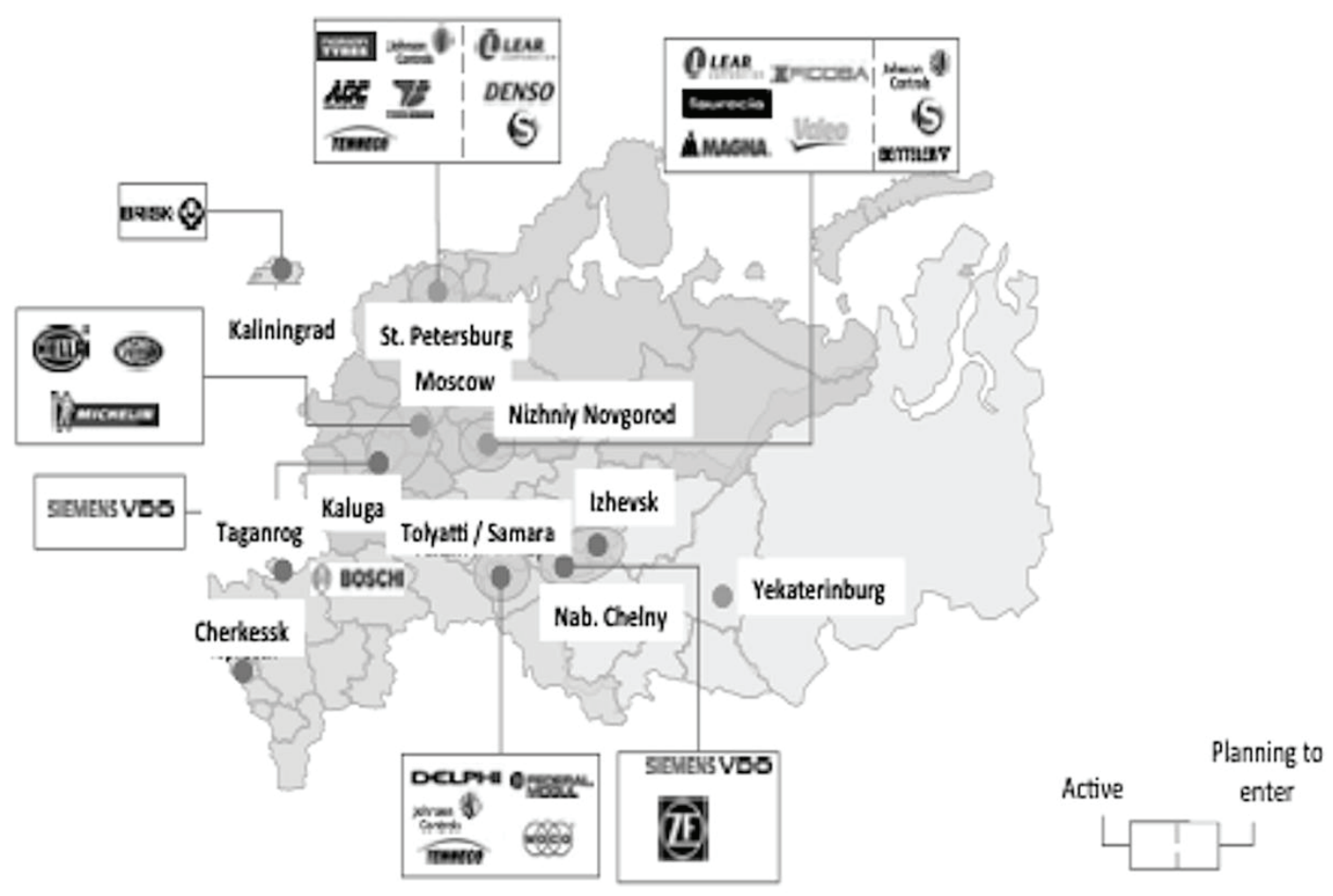

Source: Minpromtorg (2009, p. 25).

Table 2: The biggest automobile producers in Russia

\begin{tabular}{|l|l|l|}
\hline \multicolumn{2}{|c|}{ Company } & \multicolumn{1}{c|}{ The biggest domestic companies } \\
\hline AvtoVAZ (in the past VAZ) & LADA, Zhiguli (passenger) & \multicolumn{1}{c|}{ Location } \\
\hline KAMAZ & KAMAZ (trucks) & Samara Region \\
\hline GAZ & $\begin{array}{l}\text { passenger: GAZ (Volga), light commercial } \\
\text { vehicles: Gazelle, Sobol', trucks: Ural, } \\
\text { buses: PAS, KAVZ, LiAZ }\end{array}$ & Nizhnij Novgorod Region \\
\hline \multicolumn{2}{|c|}{ Company } & The biggest companies with foreign participation \\
\hline Avtotor & BMW, Kia & \\
\hline Avtoframos & Renault & Kaliningrad Region \\
\hline IzhAvto & Kia & Moscow \\
\hline TagAZ & Daewoo, Hyundai & Udmurt Republic \\
\hline Ford-Vsevolozhsk & Ford & Rostov Region \\
\hline GM-AvtoVAZ & Chevrolet-Niva & Leningrad Region \\
\hline
\end{tabular}

Source: Author. 
Figure 6: Top brands in the Russian car market by market share

Market share bybrand in terms of volume, $\%$
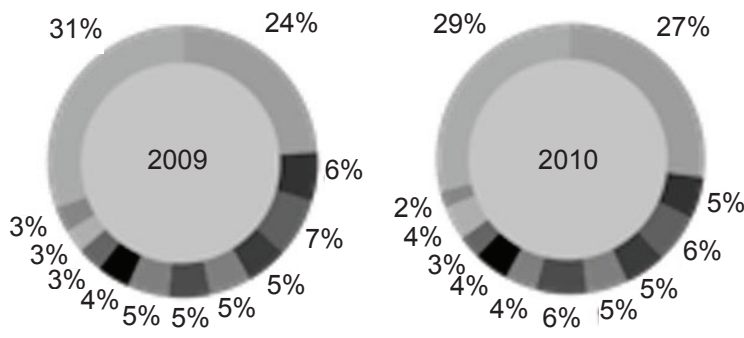

Source: AEB; Ernst \& Young estimates.

AvtoVAZ / LADA still remaining the absolute leader). This also creates perspectives for the Central and Eastern European business.

\section{Managerial Implications}

As can be seen from the figures stated above, both retail trade and the automotive industry remain less saturated and concentrated sectors and, therefore, are lucrative for foreign investors. Their main specific, in reference to the posed research question, is the high presence of big domestic companies, which creates a specific economic structure, compared with the Central European markets. The anticipated development of both sectors (both by the author and by Russian ministries' predictions) also supports hypothesis $\mathrm{H} 1$.

Gathering detailed information on Russian industries is, nevertheless, not an easy task. There are two main obstacles for doing so: 1) not enough sources in English or in Central European languages (for example, in the Czech Republic, there is only more or less one detailed presentation of the Russian business environment, Semetkovský and Duricová, 2013), 2) absence of qualified researchers or business people willing to share their experience with the public. This article, therefore, aids in overcoming these problems.

\section{References}

Bolotov, I. (2013). The Recent Development of Selected Russian Industries And Perspectives For Foreign Investors. Mimeo.

Dries, L., Reardon, T., Swinnen, J. (2004). The Rapid Rise of Supermarkets in Central and Eastern Europe: Implication for the Agrifood Sector and Rural Development. Development Policy Review, 22(5): 525-556.

Drtina, T. (2010). Crisis influences the shopping behavior of the Czech population and the promotional communication of retail chains, (accessed August 20, 2013),

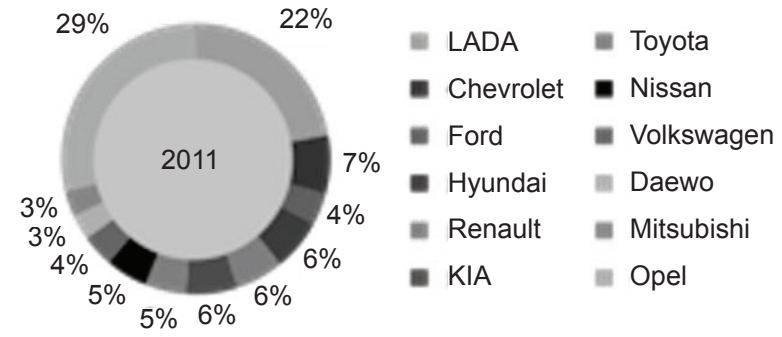

[available at http://www.incoma.cz/en/ols/reader. aspx?msg=1093\&lng=EN\&ctr=203].

Engle and Granger (1987). Cointegration and Error Correction: Representation. Estimation and Testing, Econometrica, 55: 251-276

Ernst and Young (2011). Retail trade survey 2011 (in Russian).

Ernst and Young (2013). An overview of the Russian and CIS automotive industry. March 2013.

GfK (2007). Shopping Behaviour in Russia: Trends and Features 2007. Moscow: GfK.

GfK (2012). Shopping Monitor, 2012. Prague: Incoma GFK.

Igan, D., Suzuki, J. (2012). The Wal-Mart Effect in Central and Eastern Europe, Journal of Comparative Economics, 40(2): 194-210.

Machek, M. (2012). Retail Market Structure Development in Central Europe, Central European Business Review, 1(3): 22-27.

Minpromtorg (2009). Strategy for the automobile industry for 2009-2020, (accessed August 20, 2013), [available at http://www.minpromtorg.gov.ru/ministry/strategic/ sectoral/10].

Rosstat. Databases.

Semetkovský, L., Ďuricová, I. (2013). Byznys v Rusku. Latsia, Cyprus: Primoco Investments Limited. Self-published.

Author

Ing. Ilya Bolotov, MBA, Ph.D.

Assistant Professor

Department of International Trade

Faculty of International Relations

University of Economics, Prague

13067 Praha 3, nám. W. Churchilla

ilya.bolotov@vse.cz

This article was elaborated in the framework of the Faculty of International Relations institutional support No. IP200040. 


\section{Appendix no. 1: Industry composition of the Russian economy in 2012}

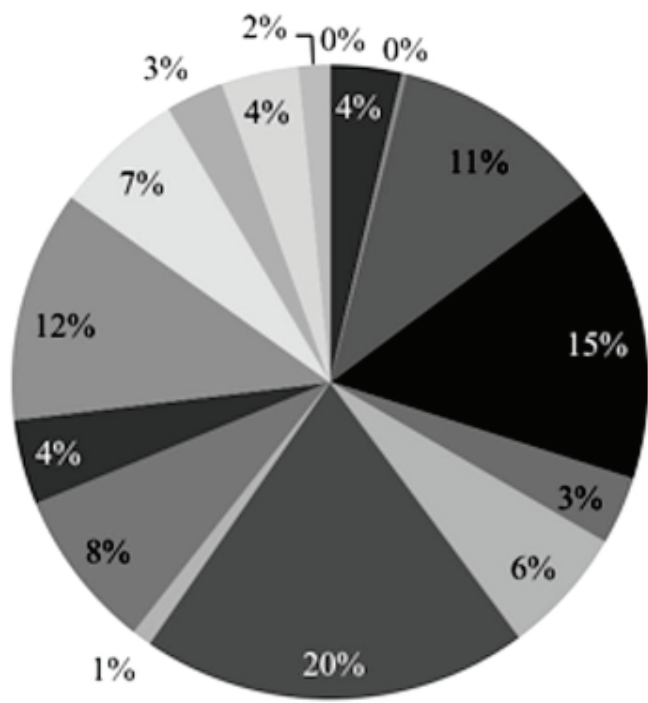

- Section A: Agriculture and forestry

= Section B: Fishing

- Section C: Mining and quarrying

- Section D: Manufacturing

= Section E: Electricity, gas, steam and air

conditioning supply

"Section F: Construction

- Section G: Wholesale and retail trade;

repair of motor vehicles and motorcycles

$=$ Section $\mathrm{H}:$ Accommodation and food

service activities

- Section I: Transportation and storage

- Section J: Financial and insurance

activities

- Section K: Real estate activities

Section L: Public administration and

defence; compulsory social security

" Section M: Education

Section N: Human health and social work

activities

= Section O: Other service activities

" Section P: Activities of houscholds as

emplovers: undifferentiated goods- and

Note: OKVED - All-Russian Classification of Types of Economic Activities. The sections are similar to the ones of the EU-NACE and of the UN ISIC, but for the order.

Source: Rosstat, author's own work / calculations 